\title{
EXTRINSIC AIDS IN THE INTERPRETATION OF STATUTES ${ }^{1}$
}

\section{FrEDERICK J. DE SLOOVk̀RE $\dagger$}

An important step in the progress of the law today is the development of judicial and administrative techniques for interpreting and applying legislation. When fully developed these will be similar at many points to techniques for interpreting and applying the common law because of analogies to the latter implicit in the whole judicial process of statutory construction; for decisions interpreting statutes have swung from narrow, literal interpretation (always seemingly objective) to broad, equitable attitudes (always seemingly subjective). Between these two extremes, various approaches-whether analytical, historical, or sociological - can be discovered as compromises between attitudes of strict and liberal construction; or between beliefs that the statute in the given case is either a rule or a principle ${ }^{2}$ to be applied upon analogies to the application of rules and principles of the common law. In this contest for theories for the judicial handling of legislation, the broad backgrounds of enactments as found in the evils. which brought them about and in their internal evolution have until recently been sadly overlooked. It is now believed that had Mr. Justice Story seen the original draft of Section 34 of the Federal Judiciary Act, inserted as a Senate amendment, the Court would not have excluded the common law from the meaning of the word "law" in the famous case of Swift $v$. Tyson, ${ }^{3}$ upon which the federal courts have depended for

I. Though statutes in pari materia and relevant to the common law doctrines are as much a part of the whole context of a statute as the internal and external history of the bill, the are not dealt with in this paper since the approach to their use is quite different from that of factual extrinsic aids. Nor are the use of extrinsic aids in the interpretation of constitutions dealt with. For an interesting treatment of the whole question of the use of extrinsic aids in constitutional construction, see ten Broek, Use by the United States Supreme Court of Extrinsic Aids in Constitutional Construction (1939) 27 CALIF. L. REv. I57. Similarly, contemporaneous administrative and executive construction, as well as usage--in the sense of popular custom before the enactment, e. g., Delaplane v. Crenshaw \& Fisher, 15 Gratt. 457 (Va. 1860) or practical construction by courts, e. g., Stuart v. Laird, I Cranch 299 (U. S. I803), are likewise not treated here; for although they are important extrinsic aids they are not strictly part of the contextual background of the language of the statute; nor are there any special difficulties as to their use. Indeed, they are always admissible, the question being one of their relevancy or weight in the opinion of the particular court.

$\dagger$ A. B., I909, LL. B., I9I2, S. J. D., I917, Harvard University; Professor of Law, New York University; editor of CASES oN THE INTERPRETATION OF STATUTES (r93I); author of other articles in legal periodicals.

2. "The technique, however, of using the statute as determinative of basic premises is utterly alien to the traditional attitude of Anglo-American law." Landis, The Study of Legislation in Law Schools (I93I) 39 HARV. GRAD. MAG. 433, 436. See also Landis, Statutes and the Sources of Law in HARVARD LEGAL ESSAYS (I934) 213.

3. I6 Pet. I.(U. S. I842). 
nearly a century when interpreting state $10,{ }^{4}$ and which finally had to be overruled as unworkable. ${ }^{5}$ It is therefore a hopeful sign that courts are turning to extrinsic materials and the history of legislation as aids in construction, for when carefully studied these give a broad and deep grasp of the contextual implications of statutory language for application to cases by the courts.

Regarding only the language of statutes, using canons of linguistic construction to justify meanings decided upon, attempting over-analytical and historical approaches in order to fit statutes into the common law, and taking attitudes of strict or liberal construction based on subjective views of the ultimate ends of particular legislation are some of the devices by which courts reach the so-called legislative intent and thereby avoid the labor of studying the history of the bill from which may be gleaned a better understanding of legislative objectives and upon the basis of which a more discriminating choice may be made from the possible meanings the language may fairly bear. Moreover, a full use of extrinsic aids would tend to curtail the practice of fabricating "fictitious intents of legislatures" by which courts "conceal the fact that they rather than the legislature were in this instance the law givers. . ..." 6

As they now function, canons of construction and judicial precedents limiting the use of extrinsic aids are, fortunately, regarded as only persuasive. This is clear from the fact that such canons, not unlike the maxims of equity, are generally cited in order to justify conclusions reached some other way, as, for example, through modern interpretive techniques that are now developing to work equitable adjustments in each case between the general or mediate ends and the specific or immediate ends of the legislation involved. That courts cannot with canons of construction and linquistic techniques achieve such adjustments without full use of extrinsic aids is coming to be recognized. ${ }^{7}$ Such canons of construction as have been cherished in the common law itself, founded as they are upon an enthusiasm for literalness, naturally militate against a liberal view of interpretation and a liberal use of extrinsic

4. Charles Warren, New Light on the History of the Federal Judiciary Act of I789 (I923) 37 HARV. L. REv. 49, 5I-52. Similarly, Judge Baldwin points out that a survey of the remarks of the chairman of the committee in charge of the bill which became the Sherman Anti-Trust Act, to the effect that the phrase, "restraint of trade and commerce", meant to be declaratory of the common law and therefore to prohibit only unreasonable restraints, might have prevented much uncertainty and error. BALDWIN, THE AMERican Judiciary (1905) 97.

5. Erie R. R. v. Tompkins, 304 U. S. 64 (1938).

6. Landis, $A$ Note on "Statutory Interpretation" (I930) 43 HARv. L. REv. 886.

7. Ibid. See also Miller, The Value of Legislative History of Federal Statutes (1925) 73 U. OF PA. L. Rev. 158; Chamberlain, The Courts and Committee Reports (I933) I U. OF CHI. L. REv. 8I, 87. In the last century, when statutory interpretation was practically literal interpretation, many of these canons were misapplied. 
aids today. 8 Some of these are valuable, however, in crystalizing the common experience of the past with respect to defining the limits beyond which it may well be injudicious to go in interpreting legislation. Modern techniques for handling statutes and materials significant in their interpretation, now rapidly developing, not only differ materially from the content of these canons, but differ also from principles, theories, and techniques employed for interpreting and applying the common law. ${ }^{9}$ Significant differences are similarly found with respect to the use and purpose of extrinsic aids in the interpreting of statutes and of other writings. ${ }^{10}$ But courts have at last come to realize the significance of what goes on behind the scenes in enacting modern legislation, even though an unfortunate hesitancy persists in employing all such sources of information.

It is submitted, however, that whatever theories may be devised to use or exclude parts of the legislative history of a statute and to weigh admissible extrinsic aids, their use must depend not upon whether a legislative intent, in its variant meanings from application in specific cases to legislative objectives, is actually discoverable, but rather upon whether they are relevant and helpful in applying the statute in particular cases. In disposing of actual cases, the courts will find valuable aid in reference to the whole context of the statute: possible linguistic meanings, relevant canons of construction, legislative objectives as gleaned from the evils (in law and fact) which gave rise to the legislation, the atmosphere in which it was enacted as derived from circumstances relevant to its evolution, ${ }^{11}$ as well as statutes in pari materia and the common law : they are refined lines of thought by means of which solutions of difficult cases may be made more real. "The records of legislative assemblies," we are told, "once opened and read

8. For example, if the words of a statute are plain and explicit, extrinsic aids are inadmissible; also, "absoluta sententia expositore non indiget"-an absolute, unqualified sentence (or proposition) needs no exposition, Co. 2D INST. *533; "Quoties in verbis mulla est ambiguitas ibi mulla expositio contra verba expressa fienda est" - when there is no ambiguity in the words, then no exposition contrary to the express words is to be made. Co. LITT. *I47. See also note I3 infra.

9. Landis, Statutes and Sources of Laze, note 2 supra; Freund, Interpretation of Statutes (I917) 65 U. of PA. L. Rev. 207; Pound, Spurious Interpretation (1907) 7 CoL. L. REv. 379 ; Pound, Common Law and Legislation (1908) 21 HARv. L. REv. 383 ; Beutel, The Necessity of a New Technique of Interpreting the N.I. L.-The Civil Law Analogy (I93I) 6 TULANE L. REV. I, 6.

10. See infra pp. 536-544.

II. This refers to the internal history of the bill from its introduction to approval by the executive. The important steps here are its introduction, drafting, printing, reference to a committee, hearings, reports of relevant testimony, of its possible favorable or unfavorable effects, with supplementary reports of those of the committee for or against it, suggested changes or amendments, debates in either House, amendments, engrossing, voting, with reports of joint committees appointed to iron out differences in the views of the two Houses, and the veto or approval of the executive with reasons if any. See note 127 infra. 
with a knowledge of legislative procedure often reveal the richest kind of evidence." 12

For these reasons it seems necessary to discover ( $I$ ) the possible tests for considering extrinsic aid; (2) how far their use depends on techniques developed for interpreting other writings; (3) how far the law has progressed in using such aids; and (4) what principles may be laid down as a basis for their effective use in the future.

\section{Possible Tests for Considering Extrinsic Ams}

There are at least three approaches to the problem of using extrinsic aids in statutory interpretation: (I) Restrict interpretation to the statutory text, statutes in pari materia, decisions interpreting the statute, and the common law, and avoid using any factual extrinsic aids even when there are patent ambiguities. ${ }^{13}$ (2) Admit factual extrinsic aids as part of the contextual process, not to change a plain meaning but only to clear up doubts in the statutory text itself-patent ambiguities - or doubts arising from application of an apparently clear meaning-latent ambiguities. ${ }^{14}$ (3) Permit full discretion in determining the relevancy of extrinsic aids not only to clear up patent or latent ambiguities in the text, but also to check an apparently plain and explicit meaning, provided that their relevancy and value are always clearly understood.

Of the three, the first must be wholly discarded. It is based upon the false assumption that there is never any actual intention of the legislature except as may be found from the words and that by confining interpretation to the statutory language the social interest in certainty and predictability of law is more fully secured. It wholly overlooks the value of the backgrounds of legislation in reaching nicer approximations of legislative objectives in application, disregards the ramifications of meaning that language will fairly bear, and underestimates the possibilities of error that lurk in the assumption that the context of the

12. Landis, note 6 supra, at 888.

I3. For a discussion of the disapproval of this distinction as to wills, see Joseph Warren, Interpretation of Wills-Recent Developments (1936) 49 HARV. L. REv. 689,

In fact exclusion of all extrinsic aids has been suggested for wills; and it is not much narrower than the English approach to statutory construction even today. See the dissenting opinion of Holt, C. J., in Cole v. Rawlinson, I Salk. 234, gr Eng. Rep. R. 207 (I702), discussed in Thayer, Pretiminary TrEatise on EvidenCE (1898) 426 et seg.

I4. Edrich's Case, 5 Co. II8a, 77 Eng. Rep. R. 238 (I603) ; Crawford v. Spooner, 6 Moore I, 13 Eng. Rep. R. 582 (1846) ; Pocock v. Pickering, I8 Q. B. 789, II8 Eng. Rep. R. 298 (1852) ; Christopherson v. Lotinga, I5 C. B. N.'S. 809 (I864). Modern American cases on this point are legion. See, e. g., Lederer v. Real Estate Title Ins. \& Tr. Co. of Phila., 295 Fed. 672 (C. C. A. 3d, I924); Work v. United States ex rel. Rives, 295 Fed. 225 (App. D. C. I924). As to latent and patent ambiguities see Joseph Warren, note I3 supra, at 705 et seq., where the distinction between patent and latent ambiguities, based on Bacon's Maxims and carried forward by writers and courts, is considered confusing and unworkable in the interpretation of wills. 
whole statute, as finally enacted, is identical with its terminology while in the making. ${ }^{15}$ This attitude can be satisfactory only in periods of simple law making when conditions giving rise to legislation can be understood without intensive study or special investigation. ${ }^{\mathbf{1 6}}$

The second theory, which is the usual approach of courts today, is stated by Bruncken from its broadest point of view as follows:

"In all cases of doubt regarding the meaning of the words, the texts should be construed to mean that which the legislator would himself have expressed if he had been in possession of all the relevant facts which the court finds to exist at the time of rendering its decision. This does not mean, of course, that the court is to be at liberty to substitute for the provisions of the statute other provisions which he deems to be more closely adapted to the circumstances of the time, but that of several possible constructions, that is to be chosen which is most apt, under the circumstances actually existing, to lead to the desired result, to wit: the maintenance of social order." 17

Unfortunately, however, extrinsic aids are regarded as irrelevant and hence inadmissible by this theory if the court feels that the statute is "plain and explicit", 18 because, it is said, since a statute that is plain needs no construction, extrinsic aids are unnecessary, for their only effect would be to contradict or vary its plain meaning. But such reasoning overlooks the necessity of bringing out all possible meanings the words may bear; it overlooks the importance of the clearest determination of statutory purpose and legislative policy and of all possible implications of the text necessary to give full effect to the technique of choosing the most satisfactory meaning the words will honestly bear in view of statutory objectives. ${ }^{19}$ It is therefore erroneous to assume that extrinsic factual aids have no value in shedding new light upon

15. Bruncken, Interpretation of the Written Law (I9I5) 25 YALE I. J. I29, I30. But compare the following from Ogden \& Richards, The MEaning of MEANING (3d ed. I930) 53, "When a context has affected us in the past the recurrence of merely a part of the context will cause us to react in a way in which we reacted before. . . .

"For these reasons, any theory of interpretation which can refrain from making images a cornerstone has clear advantages over those which cannot." Id. at 62 . See also id. at 55-56.

I6. "We inherited no legislative technique and the simpler conditions of our earlier lawmaking did not seem to call for it." POUND, THE FORMATIVE ERA OF AMERTCAN LAW (1938) 67.

17. Bruncken, note I5 supra, at I35. For a case within this rule but making liberal use of the entire history of the act and of the times and conditions of the people, and taking a broad view as to judicial notice, see State v. Kelly, 7I Kan. 8II, 8I Pac. 450 (Ig05).

I8. Hamilton v. Rathbone, I75 U. S. 4I4 (1899); Caminetti v. United States, 242 U. S. 470 (IgI7), especially the dissenting opinion of McKenna, J., at 496. For other authorities, see 2 SutherLand, STATUTORY CONSTRUCTION (2d ed. 1904) \& 367 et seq.

Ig. Davies, The Interpretation of Statutes in the Light of Their Policy by the English Courts (1935) 35 COL. L. REv. 5 Ig. 
language that only appears to be plain. ${ }^{20}$ It would be fallacious to reason that any other discoverable meaning would contradict the one already found since such an argument would find its basis in a rulethat evidence may be admitted to explain but not to contradict a writing-which ignores the fact "that no logical distinctions can be drawn between 'explanation' and 'contradiction.'" 21 Furthermore, what may, indeed, appear to be plain, may upon a broader survey turn out to be quite ambiguous; new possibilities of meaning are not a contradiction of the one first chosen. In short, a construction derived from a study of the internal and external history of the legislation in question is much more dependable than one gleaned from the statute itself. It is significant-and understandable-that statements are now appearing that this broader contextual background should be considered even when the text is apparently susceptible of only one meaning. ${ }^{22}$ Instead of applying high rules of exclusion at this point, ${ }^{23}$ admission of further aids should be solely within the discretion of the court, so that erroneous application of statutes to cases may be avoided whenever possible. ${ }^{24}$ In fact, such mistakes arise either because all possible contextual implications of the language are not discovered or because a clear insight into legislative objectives is blocked by the well established rule that a meaning which accords with the context as determined from the writing sufficiently declares the statutory purpose. ${ }^{25}$

The third theory is the only practical one for construing modern legislation. ${ }^{26}$ Although, as pointed out, full use of extrinsic aids is de-

20. Examples of this position, that a plain statute is conclusively so, are: Wilbur v. United States ex rel. Vindicator Consolidated Gold Mining Co., 284 U. S. 23I (I93I); United States v. Shreveport Grain \& Elevator Co., 287 U. S. 77 (1932) ; Fairport P. \& E. R. R. v. Meredith, 292 U. S. 589 (1934). Explanatory statements of a senator in connection with the report of the majority of the committee can be admitted to confirm a plain meaning, not to create ambiguities. United States v. Missouri Pac. R. R., 278 U. S. 269 (I929) ; Lederer, Collector v. Real Estate Title \& Trust Co., 295 Fed. 672 (C. C. A. 3d, 1924); Work v. United States ex rel. Rives, 295 Fed. 225 (App. D. C. 1924). It is repeatedly affirmed in England that it is not open to the Courts to regard a statute in the light of its social or parliamentary history. ALLEN, LAW IN THE MAKING (I927) 280.

2r. Smith, Interpretation in English and Continental Law (3d Ser. 1927) 9 J. Soc. COMP. LEG. I53, I58.

22. "It is difficult to see how it is possible to determine whether the words are capable of being taken in more than one sense without having regard to their purpose and surroundings." Davies, The Interpretation of Statutes in the Light of Their Policy by the English Courts (I935) 35 CoL. L. REv. 519, 527.

23. See infra pp. $545,546$.

24. See Lee, Book Review (Ig24) 24 CoL. L. Rev. 214, 215.

25. The cases so holding are legion. For example, there is no room for interpretation if the language is clear. United States v. Missouri Pac. R. R., 278 U. S. 269 (I929). No reports of legislative committees can be considered for the purpose of contradicting (finding new meanings for) what appears to be the only meaning of the words. Pennsylvania R. R. v. International Coal Mining Co., 230 U. S. I84 (I9r3); United States v. Shreveport Grain \& Elevator Co., 287 U. S. 77 (1932) ; (1933) II TEx. L. REv. 562, 564 (I933). See note I8 supra.

26. As yet, there is little authority for this position. "While the language of the act itself seems clear, and its meaning unmistakable, the debates attending its passage, conducted largely by members of the committees in charge of the measure, are instruc- 
sirable as a check against an erroneous reliance on apparently plain meanings or as a wider contextual background for satisfactorily understanding long and complicated legislative enactments of today, on the other hand, venturing into the unchartered realm of factual backgrounds of legislation, as found in its legislative history, is still a perilous journey, ${ }^{27}$ especially if the reason for the journey is not clearly understood. Though no rigid rules should prevent such excursions, which should be entirely within the discretion of the court, no search should be made for an expression of legislative intention with respect to the very case at hand or as a basis for guessing what the legislature would have done with the case at hand or for individual opinions, as distinguished from facts or conditions, set forth in reports and debates. In such a search these should be studiously avoided as ends, even though every one of them may be of value as part of the entire background or atmosphere out of which the legislation was enacted. The search rather should be made only (I) to determine the broader contextual meanings of the statutory language; (2) to clarify the purpose or objectives of such legislation in view of the existent evils, the suggested remedies and the relevant customs and usage both before and after its enactment; and (3) to use this knowledge not only to choose the best meaning in view of these objectives, but also to apply the statute so as to give them full effect. In all three instances, extrinsic factual aids should be employed only from the most clear and authoritative sources, which are as much a part of the context as are statutes in pari materia and the common law.

As regards the use of these auxiliary aids, several further questions present themselves. Are they to be regarded as evidence, as some courts seem to think? And if so, to what extent are evidentiary rules of exclusion to be applied? ${ }^{28}$ What further distinctions are to be made when such evidence is to be used by a court, and when it is to go to a jury as an aid in applying a statute? First, it seems clear that when such extrinsic matters are addressed to a court they should not be treated as evidence and should not be affected by any rules of evidence but relevancy. For example, in Gaylor's Appeal ${ }^{29}$ the question was whether it was necessary in making a will that the witnesses subscribe their names in the presence of each other. The statutes provided only that wills be "subscribed by the testator, and attested by three witnesses, all of them subscribing in his presence." Testimony to the effect

tive as emphasizing the predicament of the railroads sought to be relieved, and reveal clearly the true legislative intent." Van Valkenburgh, J., in United States v. Great Northern Ry., 57 F. (2d) 385,390 (C. C. A. 8th, 1932). Legislative history may be admitted to show there was no support for the construction of the court below. United States v. Raynor, 302 U. S. 540 (1938).

27. See Pine Hill Coal Co. v. United States, 259 U. S. I9I, I96 (I922).

28. See infra pp. $542-544$.

29. 43 Conn. 82 (1875). 
that it was the practice of lawyers in Connecticut to have witnesses always subscribe their names in the presence of each other was rejected on the ground that the question was one of law and not one of fact for the jury. The court pointed out that extrinsic aids are not subject to rules of evidence at all ; that although the judge might call to his aid "the wisdom and experience of eminent counsel", he was not bound to do so, and his refusal was not error..$^{30}$ So far as factual extrinsic aids are used in determining the meaning of legislation, they should likewise be regarded as questions of law for the court ${ }^{31}$ in the same manner as contemporaneous judicial or administrative construction, statutes in pari materia and the common law. In problems of construction, therefore, the court should be free from all restrictions of exclusionary rules. This was set forth by the Supreme Court in a case dealing with the question as to which a statute takes effect as follows:

"... whenever a question arises in a court of law of the existence of a statute, or of the time when a statute took effect, or of the precise terms of a statute, the judges who are called upon to decide it have a right to resort to any source of information which in its nature is capable of conveying to the judicial mind a clear and satisfactory answer to such a question; always seeking first for that which in its nature is most appropriate, unless the positive law has enacted a different rule." 32

This position is by no means new. In Attorney-General v. Cast-Plate Glass $\mathrm{Co}^{33}$ what the words "squaring glass into plates" meant was held to be a pure question of law, and hence extrinsic evidence was inadmissible as such. The court adds that the "judge . . . must form his judgment of the meaning of the legislature in the same manner as if it had come before him by demurrer. . . ." 34 This does not mean, however, that no extrinsic factual aids may be consulted. In fact, the court goes on to say that even "on demurrer, a judge may well inform himself from dictionaries or books on the particular subject. . .".35

Now freedom from rules of exclusion may be put on the theoretical ground of affording a refreshing of recollection of things which can be judicially noticed or may be explained as performing the purpose

30. Ibid. See also Attorney General v. Cast-Plate Glass Co., I Anst. 39, I45 Eng. Rep. R. 793 (I792).

31. Gaylor's Appeal, 43 Conn. 82 (1875). The authorities are legion.

32. Gardner v. Collector, 6 Wall. 499, 5II (U. S. I867). Professor Gray believed that the words in the opinion, "always seeking for that which in its nature is most appropriate" are ambiguous, and hinted that they should not be construed to put limitations on the use of extrinsic aids beyond the good judgment of the court itself. GRAY, The Nature and Sources of THE LAW (2d ed. I92I) I69. For example, definitions in standard dictionaries are admissible. People v. Borda, Io5 Cal. 636, 38 Pac. IIIo (I895) ; Penn. Co. v. Mosher, 47 Ind. App. 556, 94 N. E. I033 (Igrr).

33. I Anst. 39, I45 Eng. Rep. R. 793 (I792).

34. Id. at 44,145 Eng. Rep. R. at 795 .

35. Ibid. 
of informing the court on preliminary questions of law or fact. ${ }^{36}$ Thus the question of statutory meaning, whether one of law or a mixed one of law and fact, should always be for the court. ${ }^{37}$ So far as statutory interpretation involves questions of fact that may be regarded as preliminary questions of fact ${ }^{38}$ or of fact involved in a question of law, making it a mixed question of law and fact, they are of course exclusively for the court. And it should make little difference whether the meaning of statutory language depends (I) on such non-legal matters as grammar, rhetiric, reason, logic, common sense; or (2) on ordinary commercial or technical meanings of words and phrases as found in dictionaries or in the usage or customs of a trade, business or profession; ${ }^{30}$ or (3) on the contextual implications of language as found in the internal history of the legislation; or (4) on social, economic or industrial evils and conditions as found in contemporaneous history: in each case they can be used only in conjunction with a variety of legal questions, such as the relation of the statutory language to other parts of the statute, to other statutes in pari materia, and to the common law. ${ }^{40}$ They are all part of the linguistic process which, with all its factual aids and merged with legal interpretation in a "judicial synthesis", 41 is applied to the case at hand in the light of all law and the entire judicial process. That their use be unrestricted and that precedents be regarded as directory would seem to follow logically. Indeed, the question on appeal is always whether the lower court found the proper statutory meaning, not whether the means employed by it were in accord with precedents dealing with limitations on the use of extrinsic aids. ${ }^{42}$

36. "But the true conception of what is judicially known is that of something which is not, or rather need not, unless the tribunal wishes it, to be the subject of either evidence or agument-something which is already in the court's possession, or at any rate is so accessible that there is no occasion to use 'any means to make the court aware' of it." ThaYer, CASES ON EvIDENCE (Ist ed. I892) 20. See also Maguire and Epstein, Preliminary Questions of Fact in Determining the Admissibility of Evidence (1927) 40 HARV. L. REv. 392.

37. Winchell v. Camillus, I09 App. Div. 34I, 95 N. Y. Supp. 688 (4th Dep't I905); Belt v. Marriott, 9 Gill 33 I (Md. I850).

38. Thayer, Preliminary TrEatise on EVIDENCE (I898) 202 et seq.; Thayer, "Law and Fact" in Jury Trials (I890) 4 HARv. L. REv. I47; I HoLDsworTH, A HISTORY OF ENGLISH LAW (3d ed. rg22) 345 .

39. de Sloovère, The Functions of Judge and Jury in the Interpretation of Statutes (1933) 46 HARV. L. REv. I086, I088.

40. Id. at rogo, I09r. 582.

4I. Pitamic, Some Aspects of the Problem of Interpretation (I933) I9 A. B. A. J.

42. This question seems implicit in the cases on appeal. Peoples $\mathrm{Y}$. Stephens, 7r N. Y. 527,537 (1878); Bank of Pennsylvania v. Commonwealth, I9 Pa. I44, I48, I56 (I852). See also Blake v. National Banks, 23 Wall. 307, 317 (U. S. 1874); United States v. Union Pacific R. R., 91 U. S. 72, 79 (1875); Blake v. United States, Io3 U. S. 227,235 (I880).

"While the opinion of a member of the legislature which passed an act, or that of the comptroller general, as to its meaning and purpose, might possibly often be valuable and instructive in construing the act and arriving at the legislative intent, it cannot be 


\section{Analogies to Other Writings}

Fear and over-conservatism in the judicial handling of these aids in statutory interpretation ${ }^{43}$ are due in part to an overemphasis in the last century of language devices in textual interpretation and of general canons of construction as corollaries thereof, because these appeared to preserve certainty and predictability of law; in part to taking analogies to the interpretation of other writings which put strict limitations on the use of extrinsic aids; ${ }^{44}$ and in part to a failure to realize that changes in social, industrial, and economic conditions have brought about more carefully framed legislation than formerly, ${ }^{45}$ which in turn requires more flexible interpretive techniques if we are to reach below the surface of the modern statute and appreciate its real import. ${ }^{48}$ The basis for the development of such techniques is a belief in the value of the broadest contextual background for interpretation. This is fully recognized in Continental law. ${ }^{47}$ Indeed, the Continental modes of interpretation, based on the widest contextual approach, go far in permitting the use of all extrinsic aids, especially the internal history of the legislation; and those versed in its history are regarded as especially competent to interpret it. ${ }^{48}$ Although reasoning by analogy is perhaps

seriously contended that courts can properly resort to sources of this kind in ascertaining the legislative will as expressed in a statute. . . The motion for a new trial complains of various rulings made by the court in rejecting and in admitting evidence. It is unnecessary to state or discuss them more in detail, as they could have had no effect whatsoever upon the proper determination of the cases now under review. The correct result was undoubtedly reached, and it is therefore immaterial whether, in the rulings referred to, the court did or did not err." Stewart v. Atlanta Beef Co., 93 Ga. 12, I8-I9, I8 S. E. 981, 985 (1893).

43. For example, in Justices of Lancaster v. Mayor of Rochdale, 8 App. Cas. 494, 50I (1883), Lord Bramwell says: "I do not know historically how this Act came into existence. . . I doubt very much whether, if one did know, one would have a right to apply that knowledge to the construction of this Act of Parliament."

Parliamentary history of a statute was considered "wisely inadmissible to explain it". The Queen v. Hertford College, 3 Q. B. D. 693, 707 (1878). Reports of commissioners were said to be "scarcely legitimate guides to the construction of the statute". Rankin v. Lamont, 5 App. Cas. 44, 52 (1880), per Lord O'Hagan. In Salkeld v. Johnson, 2 Ex. 256, 273, I54 Eng. Rep. R. 487, 495 (I848), a report by commissioners which was the basis of legislation was held inadmissible, "however strongly we may believe that it [the statute] was introduced in order to carry into effect their recommendation."

44. Earlier, the written word seemed to outweigh all other evidence of meaning.

Davies, note I9 supra, at 522.

45. Pound, op. cit. supra note 16 , at 60 .

46. Indeed, systematizing in the field of statutory interpretation from the practical or theoretical side has been consistently ignored by the legal profession in America. As a consequence, techniques for the judicial handling of legislation in any way comparable to those developed for handling the common law have not been worked out. See Landis, The Study of Legislation in Law Schools, note 2 supra, at 440.

47. Smith, note 21 supra, at I56.

48. Gutteridge, $A$ Comparative View of the Interpretation of Statute Law (I933) 8 TULANE L. REv. I, 9-13, I9.

The early English attitude toward interpretation of legislation was in some respects much more liberal than it is today, for in the time of Henry II, when those who made the law were those who usually applied it to cases, problems of interpretation as we know them today were not surmised. This situation was changed as early as the time of Edward I. Plucknett, The History of the Rules of Statutory Interpretation (I933) 
the cornerstone of the judicial process of interpreting and applying the common law, it is at present very unlike the judicial process of choosing, interpreting and applying statutory precepts in the AngloAmerican system, since the former is based on principles, reason and analogy, while the latter treats the statute as a rule, subject to literal, not spiritual, interpretation. "For one thing," says Dean Pound, "the common law has never been at its best in administering justice from written texts. . . . It has always, in comparison with the civil law, been awkward and none too effective in deciding on the basis of legislative texts." 48

Too often courts assume that rules governing the interpretation of written instruments are applicable in the interpretation of statutes because both involve questions as to how far a document can be explained or varied by parol, ${ }^{50}$ because both assume the existence of some definite intention behind the document which is to be discovered, if possible, and because in both the interpretive process differs from interpreting common-law precepts. Thus in construing a statute courts seek to find the specific meaning of the text directly through grammar and other language techniques rather than the general idea or principle lying behind the specific statutory language. Furthermore, differences in construing statutes and other writings exceed their apparent similarities, and are also more important. First, a specific legislative intention with respect to a given case is very often a fiction, ${ }^{51}$ whereas the intention of a testator or parties to a writing in many cases is really discoverable. In cases of wills, for example, the problem is to regard the meaning of the words (unless words of art) as only a point of departure for arriving, if possible, at the real intention of the testator, ${ }^{52}$ in order to make a single disposition of property. With statutes the problem is to clarify rules or standards set up for regulation of conduct over a long period of time through the broadest contextual background, so that the precedents may approximate as nearly as possible the legislative purpose and the ends of law apart from any assumption of a legislative intention in detail. $^{53}$ This is in line with the view of Mr. Justice Holmes that one

I75 L. T. 57. Formerly it was customary for judges to go to the legislature and inquire what they meant whenever the language of an act was ambiguous or contradictory. See I CAMPBell, LIVES OF THE LORD ChanCellors (1874) $24 \mathrm{I}$ et seq.

49. Pound, op. cit. supra note 16 , at 46-47.

50. In Abernethy v. Board of Commissioners, 169 N. C. 631,86 S. E. 577 (Igr5), inadmissibility of testimony of individual members of the legislature was based on analogies to the parol evidence rule as applied to contracts. In Bank of Pennsyivania v. Commonwealth, Ig Pa. I44 (I852), evidence of public embarrassment, a message of the governor, journals of the House, and committee reports were excluded upon analogy to what appears to be the parol evidence rule.

5I. See Pound's Introduction to DE SLoovère, CASEs on the INTERPRETation of Statutes (I93r) vii.

52. THAYER, loc. cit. supra note 13 .

53. Pound, Spurious Interpretation, note 9 supra. 
lets in extrinsic aids not to find out what the speaker meant but what a normal person would mean, using that language under similar circumstances. ${ }^{54}$ The phrase, "intention of the legislature", therefore connotes no more than the most satisfactory meaning that the words will honestly bear in view of the actual conditions and evils toward the elimination of which the particular statute was directed. ${ }^{55}$ One might complain that pointing to a discoverable legislative purpose as distinguished from a legislative intention (often non-discoverable) is a distinction without a difference. Yet the difference between the general trend of thought underlying a statute (purpose) and close questions as to textual meaning that arise only upon application in a given case ${ }^{58}$ -the difference between the particular objectives of a piece of legislation, which in and of themselves do exist in the minds of the legislators at the time of enactment and which are quite discoverable through extrinsic aids, and the minutiæ of meaning necessary to apply it (with all its contextual implications in view of a particular case) which can seldom be in the minds of a majority of the legislators-is quite clear and important.

The fact of the absence of legislative intent, however, may well be driven too far. It has often been stated that there is never any discoverable legislative intention. ${ }^{57}$ If by "legislative intent" is meant the minutia of meaning in application to specific cases, then rarely does such intention exist. Just as rarely, however, is the phrase so used by lawyers or courts, for normally it connotes only the meaning as found from the language and its broadest contextual background of internal and external circumstances, with the aid of canons and techniques of interpretation. Perhaps every one would concede that some aspects of the history of a statute ${ }^{58}$ are relevant to its interpretation. Not to concede the existence of at least a discoverable purpose in legislaive

54. Holmes, The Theory of Legal Interpretation (I899) I2 HARV. L. REv. 4I7, 4I8.

55. ". . . all latitude of construction must submit to this restriction, namely, that the words may bear the sense which by construction is put upon them. If we step beyond this line, we no longer construe men's deeds, but make deeds for them." Eyre, C. B., in Gibson v. Minet, I H. B1. 569, 615, I26 Eng. Rep. R. 326, 352 (I79I), quoted in THAYER, op. cit. supra note 13 , at $4 \mathrm{II}$. A corollary of this rule, one commonly employed for other writings, applies, namely, that "no effect is to be given to what is not expressed in the writing." THAYER, op. cit. supra note 13 , at 443 . See also Schooner Paulina's Cargo v. United States, 7 Cranch 52 (U. S. I8I2). For Judge Baldwin there was justification for spurious interpretation by contradicting the plain meaning in order to work justice by giving effect to "the judge-discovered intent". BALDWIN, THE AMERICAN JUDICIARY (1925) 84.

56. Indeed, at this point of ambiguous language of a statute, the solution depends largely on what school of interpretation the interpreter follows, for in reality the only legislative intention is to empower courts to find the most satisfactory meaning the statutory words will bear by fair use of the language. THAYER, op. cit. supra note I3,
at $4 \mathrm{II}$.

57. See, for example, Radin, Statutory Interpretation (I930) 43 HARv. L. REv. 863 , at 872 . Cf. Landis, note 6 supra, at 887-888.

58. Radin, ibid. 
history would be to deny any relation between what legislators do in enacting legislation as a body and what they express in the language of statutes. Similarly, casting out successive drafts of a bill ${ }^{59}$ as irrelevant is difficult to explain when statutes in pari materia are always considered relevant. Unquestionably, clarifying immediate statutory objectives and getting contextual perspective, by a study of legislative history, aid in making a choice from the possible meanings the language will bear, and such a procedure is clearly distinguishable from seeking what the legislature might have had in mind with respect to the case before the court. For Professor Radin the immediate legislative purpose is "indistinguishable from intention", while the mediate or ultimate ends or objectives of legislation are "more real". ${ }^{80}$ But as Dean Pound has pointed out, ${ }^{61}$ these ultimate ends are the real sources of spurious interpretation. They are subjective evaluations and approximations at best. So far as ultimate or mediate objectives of legislation may be indicated in its legislative history, they are, of course, of value. Otherwise, they are largely shaped by the legal or social philosophy of the interpreter, his experience or other subjective factors, or his legalistic or nonlegalistic views of the statute in question. ${ }^{62}$ No equitable interpretation of statutes need imply, however, a disregard of every bit of extrinsic evidence that will aid interpretation. If a statute means only what a court-appraising it from various perspectives, be they economic or political, historical or philosophical-wishes to think it means, even in view of future events or consequences, ${ }^{63}$ and if searching for immediate legislative objectives in the internal history of the legislation and in conditions surrounding its enactment is a misguided effort, then language techniques and juristic conceptions become the sole bases for statutory interpretation of the future, and we find ourselves back where we were a century ago in the judicial handling of legislation.

Dean Pound defines genuine interpretation as the process by which courts seek "directly what the law-maker meant by assuming his position, in the surroundings in which he acted, and endeavoring to gather from the mischiefs he had to meet and the remedy by which he sought to meet them, his intention with respect to the particular point in controversy." 84 This comes near to saying that genuine interpretation justifies the widest possible study of the context of legislation. Conversely, when he says that spurious interpretation in seeking "to reach

59. Id. at 873 .

6o. Id. at 875 .

6I. Pound, Spurious Interpretation, note 9 supra, at 38r.

62. For examples of these views of interpretation, see Pound, Enforcement of Law (1908) 20 GREEN BAG 404 et seq.

63. Radin, note 57 supra, at 875 et seq.

64 . Pound, note 9 supra, at $38 \mathrm{r}$. 
the intent of the law-maker indirectly . . . assumes that the lawmaker thought as we do on general questions of morals and policy and fair dealing", ${ }^{65}$ he again comes very near to saying that such a construction is concomitant to a disregard for extrinsic sources of information and an over-reliance on personal views. There seems to be no inconsistency, at least between genuine interpretation, as so defined, and the broadest possible use of extrinsic aids, provided only that the meaning chosen can be attributed to the words by fair use of language. Spurious interpretation, on the other hand, is likely to result, if courts read into statutory language their own views of the immediate or mediate ends, by unconscious manipulation of linguistic techniques and a free choice of canons of construction without an exhaustive study and proper evaluation of the objective, extrinsic materials that best indicate the contextual implications of the language. Certainty and predictability through literal, grammatical or even contextual interpretation, confined to the four corners of the statute, is therefore more apparent than real. But a full study of the history of legislation makes subjective meanings or conclusions, reached through political pressure, more difficult to justify. ${ }^{66}$ In a word, the more comprehensive and detailed the contextual setting becomes-through minute study of the internal history of the bill and other extrinsic aids-the less subjective becomes the interpretive process. ${ }^{67}$

If these distinctions be true, admission of extrinsic aids should not be put on the theory employed in the interpretation of wills, namely, that the closer a particular meaning approximates the actual intention of the testator without contradicting the meaning of the words, the more satisfactory it becomes. Since such a specific intention as regards a legislature is undiscoverable except perhaps where the type of case before the court was definitely in issue in the legislative history of the bill, extrinsic aids come in rather to determine the contextual meaning of the language under the circumstances of its use; and this is accomplished either by clarifying the legislative objectives, upon which the courts should consistently rely in making choices from possible meanings, or by resort to a reconstructed legislative atmosphere. ${ }^{88}$ Upon either theory, motives or opinions of legislators or other persons ${ }^{69}$ are

65. Ibid.

66. Id. at 384 .

67. "The real difficulty is twofold: that strong judges prefer to override the intent of the legislature in order to make law according to their own views, and that barbaric rules of interpretation too often exclude the opportunity to get at legislative meaning in a realistic fashion." Landis, note 6 supra, at 890 .

68. Holmes, note 54 supra.

69. A magazine article is not admissible "as evidence" of the meaning of a statute. Camas Stage Co., Inc. v. Kozer, I04 Ore. 600, 209 Pac. 95 (I922). Testimony of the chief of police and of the executive officer of the board of public utilities was held inadmissible for the purpose of showing what the legislature meant in framing a rate fixing 
logically irrelevant, while their statements of facts, conditions of the times or other factors which led to the enactment are valuable. Nor do rules as to general and particular intention in the interpretation of wills have any relation to statutory interpretation, unless the idea of a general intent is similar to statutory purpose. ${ }^{70}$

By way of analogy to other writings, then, cases hold that statutory meaning must be sought from the text itself; that extrinsic aids must be employed to explain, not "contradict", the meaning of the language; that if the text is plain, no extrinsic aids are usable; or conversely, that extrinsic aids can be brought in only to clear up ambiguities (and unfortunately for written instruments, only latent ambiguities) ${ }^{71}$ that the words of a statute are the expression of a legislative intent (as a will is the expression of the testator's intent) which is to be realized wherever possible; and that whatever meaning is found, it must at least be one which the language textually or contextually will bear. These rules, devised to attain a certainty of meaning often more apparent than real, curtail the full play of the contextual process (especially the use of circumstances dehors the writing), and prevent the interpreter from breathing the very atmosphere in which the statute was conceived and enacted. ${ }^{72}$ Rules restricting the use of extrinsic aids in

ordinance with respect to electricity. Ex parte Goodrich, I60 Cal. 4IO, II7 Pac. 45 I (I9II). The testimony of a draftsman, a member of the legislature, was held inadmissible to show that in amending a statute certain parts were inadvertently omitted (clerical error) in the amendment. Combined Saw \& Planer Co. v. Flournoy, $88 \mathrm{Va}$. I029, I4 S. E. 976 (1892). In these cases exclusion on the ground of irrelevancy would have been less misleading.

That relevancy is the basis is seen in cases holding that testimony of witnesses, acquainted with the field covered by a statute, is admissible to aid the court in coming to a conclusion as to the meaning of a word in a statute. See St. Louis, Iron Mt. \& So. Ry. v. State, I02 Ark. 205, I43 S. W. 9 I3 (I9I2); Rose v. Franklin Life Ins. Co., I53 Mo. App. 90, 132 S. W. 6r3 (1910). The following were held clearly irrelevant: evidence of comptroller-general in regard to the meaning of a tax statute, Stewart $v$. Atlanta Beef Co., 93 Ga. 12, I8 S. E. 981 (1893); opinions of members of legislature, Goins v. Trustees Indian Training School, I69 N. C. 736, 86 S. E. 629 (I915); Trent v. Fisher, I7 Hawaii 612 (I906); or testimony to explain the motives of the legislators, Pagaud v. Mississippi, 13 Miss. 49 I (1845).

70. For numerous cases dealing with general intent as synonymous with statutory purpose and as the basis for making a choice between possible meanings the words will fairly bear, see 2 SutherIaND, STATUTORY CONSTRUCTION (2d ed. I904) \$ 369 .

The distinction between interpretation and the legal effect of words of a writing resulting irrespective of intent has no significance in interpreting statutes, Of course, irrespective of actual intent, the powers or facilities as given in an instrument or statute may determine its meaning, nature and effect. See Liverpool Ins. Co. v. Massachusetts, Io Wall. 566 (U. S. 1870); Cox v. Hickman, 8 H. L. Cas. 268, 8 Eng. Rep. R. 43I (1860) The presence of technical legal terms in a statute, however, in no way obviates interpretation, since the problem of interpreting such words in the light of the common law remains. The difference is that statutes are law, whereas other writings
are not.

71. 5 WIGMORE, EVIDENCE (2d ed. Ig23) \$\$246I, 2472 et seq. See REsTATEMENT, Property (Tent. Draft No. 7, 1937) \$§ 24I-8; Powell, Construction of Written Instrnments (1939) 25 A. B. A. J. 187.

72. See Black v. Bachelder, I20 Mass. I7r ( 1876$)$, in which it was held that parol evidence as to the meaning of a written contract containing no latent ambiguity could not be considered even though such evidence had been admitted by both parties without objection at the trial. See also note 44 sipra. 
order to prevent fraud and mistake or to secure to the parties the transaction agreed upon-e. g. the parol evidence rule-have no counterparts in statutory interpretation, except with respect to impeaching statutes. ${ }^{73}$ The social and individual interests behind these rules as applied to other writings are sufficiently secured in construing statutes by the precept that the words must "bear the sense which, by construction, is put upon them." ${ }_{44}$ But this precept need not restrict in any way the fullest use of relevant materials extrinsic of the statute.

The necessity for passing from the four corners of an instrument to extrinsic matters in seeking "the true meaning" was recognized at an early date. ${ }^{75}$ Thayer tells us that by the middle of the eighteenth century extrinsic matters were of necessity beginning to be freely used in the interpretation of documents. ${ }^{76}$. Later, in the construction of wills even the testator's contemporary declarations of intention were considered admissible to explain ambiguities, if not to contradict a plain meaning. ${ }^{77}$ On the other hand, direct statements of intention or opinions of legislators even to explain ambiguities in statutes have always been excluded, not by any analogy to other writings, but because they are not evidence of legislative intention of the majority. The basic idea, then, for interpreting writings generally is the logical relevancy of evidence in view of exclusionary rules and principles of construction. ${ }^{78}$

In case of statutes, however, logical and practical relevancy of extrinsic aids depends on the issue of textual meaning raised by the case and in view of statutes in pari materia, the common law, and contextual techniques of interpretation, including canons of construction, and subject only to the limitation that as in other writings, ${ }^{79}$ extrinsic matters must not be used to reach a meaning that the text cannot fairly bear in good faith. ${ }^{80}$ That extrinsic evidence can be used to clear up latent but not patent ambiguities, ${ }^{81}$ though still found occasionally in cases on

73. Field v. Clark, I43 U. S. 649 (I892); Borough of Freeport v. Marks, $59 \mathrm{~Pa}$. 253 (I868); State ex rel. Reed v. Jones, 6 Wash. 452, 34 Pac. 201 (I893). See also 2 WIGMORE, EVIDENCE (2d ed. I923) § I350.

74. THAYER, op. cit. supra note I3, at $4 \mathrm{II}$.

75. Heydon's Case, 3 Co. 7,76 Eng. Rep. R. 637 (Ex. I584). This case laid the basis for admission of extrinsic aids in allowing the circumstances which lead to the passing of the act to be considered as well as the evils which brought about the legislation. See also Cockburn, C. J., in South Eastern Ry. v. Commissioners, 5 Q. B. D. 2I7, 236 (I880) ; Mounsey v. Ismay, 32 L. J. Ex. 55 (1865) (the occasion of the enactment) ; The Queen v. Dean of Hereford, L. R. 5 Q. B. Ig6 (I87o) (the state of things existing at the time of the passing of the act). But cf. Justices of Lancashire v. Mayor of Rochdale, 8 App. Cas. 494, 50 r (I883).

76. THAYER, op. cit. supra note I3, at 445 .

77. Mutual Life Ins. Co. v. Hillmon, I45 U. S. 285 (1892); cf. Commonwealth v. Trefethen, I57 Mass. I80 (1892); see Warren, note 13 supra, at 705 et seq.

78. ThAYER, op. cit. supra note I3, at 446 .

79. Professor Williston in his Treatise on Contracts does not go into the question how far rules for the interpretation of contracts apply to wills or statutes. 3 Wirisston, Contracts (Rev. ed. I936) \&60I.

80. THAYER, op. cit. supra note $\mathrm{I3}$, at $4 \mathrm{II}$.

81. See Warren, note I3 supra, at 705 et seq. 
wills, has never been a distinction applicable to statutes. Regarding it as an "unprofitable subtlety", Thayer states that "the only patent ambiguity that was not open to explanation by extrinsic matter was one that, in the nature of things, was not capable of explanation". ${ }^{82}$ Though in the case of wills, on the one hand, courts have gone far in admitting extrinsic facts to determine the testator's intention with respect to a specific difficulty, ${ }^{83}$ in some cases of statutes, they have not been so liberal. For example, a statute providing that no liquor should be sold within a certain distance of "Mt. Zion Church" was perfectly clear until it was found that there were two churches by that name. The statute was in the singular. It was held to be unenforceable. ${ }^{84}$ Indeed, application of the statute to the church for colored people would not have contradicted the patent meaning of the statutory words, and declaring it inoperative was due to a misunderstanding of the use of extrinsic aids. ${ }^{85}$ Extrinsic aids should always be admissible to identify acts, persons or things described in the text, whether in a statute or other writing. ${ }^{86}$

Under the broader view, then, neither rules of evidence nor the parol evidence rule should have any influence upon the question as to what extrinsic aids may be consulted by a court in the interpretation of a statute. The parol evidence rule deals with the question as to what may be considered a part of a written or integrated contract or transaction. ${ }^{87}$ In its application to statutes it takes the innocent form that the plain meaning of the text cannot be contradicted by extrinsic matters rather than the form that no meaning may be attributed to the language that it cannot fairly bear in any case. The former not only leads to difficulties as to what constitutes explanation as distinguished from contradiction, but also entirely misconceives the basic problem of statutory interpretation, namely, equitable adjustment of the statute to cases through a fair contextual meaning of the language that most nearly approximates legislative objectives. A contextual meaning may

82. ThaYER, op. cit. sipra note $\mathrm{I} 3$, at 424 .

83. See Warren, note i3 supra, at 705 et seq.

84. State v. Partlow, 9r N. C. 550 (I884). Cf. Smith v. Helmer, 7 Barb. 416 (N. Y. Ch. 1849), in which extrinsic evidence was admitted to show that a particular road was the only one answering the descriptive words of the statute. et seq.

85. ThAYER, op. cit. supra note I3, at 422 et seq.; Warren, note 13 supra, at 705

86. "We are turning signs and symbols into their equivalent realities. This must always be done to some extent, no matter how many are the identifying tokens." Cardozo, J., in Marks v. Cowdin, 226 N. Y. I38, 143, I23 N. E. 139, I4I (I919).

"In every case, the words used must be translated into things and facts by parol evidence." Holmes, J., in Doherty v. Hill, I44 Mass. 465,468 , II N. E. 58I, 583 (I887). See also LIEBER, HERMENEUTICS (I880) 4 et seq.

87. "The justification of the Parol Evidence Rule is that when parties incorporate an agreement into a writing it is a reasonable assumption that everything included in the bargain is set down in the writing." I REsTATEMENT, CoNTRACTs (I932) $\$ 240$,
comment $d$. 
justifiably supplant a grammatical one, and to regard the former as a contradiction of the latter-which is only apparently plain-is to restrict unnecessarily the explanatory process. Similarly, rules of evidence are devised to solve issues of fact (usually before a jury). They have no analogies in problems of statutory interpretation, which are questions of law or law and fact wholly for the court. To treat the admission of information dehors a statute when interpreting it as a problem of evidence is thus based on erroneous analogies to other writings, ${ }^{88}$ unless the information is to go to the jury as evidence of the meaning of words and phrases which the court feels the jury can understand as well as, if not better than, the court itself. "Courts do, indeed," says Thayer, "when engaged in this process of definition, sometimes take the opinion of the jury . . . as one that the court is willing to accept." 88 If the question of meaning is thus going to the jury, ${ }^{80}$ evidence on the matter should of course be subject to all ordinary evidentiary rules.

\section{Theories Underlying the CAses}

Instead of regarding canons of interpretation, analogies to rules for interpreting other writings, the parol evidence rule or other evidentiary rules which have tended toward restricting the search for meanings to the four corners of the statute, emphasis today should be placed rather upon the entire contextual background of the statute by recapturing the atmosphere in which the legislation was enacted. This includes such elements as prior drafts and amendments suggested at the time of enactment, reports of committees, legislative debates and opinions of those who know most about the evils in fact and law that brought about the particular enactment.91 That such elements must be relevant and reliable, with respect to the particular issue of meaning before the court, leads at once to questions of admissibility of particular phases of the internal history of the legislation. Some questions with respect to this problem are these: Is there reliable information as to what the legislature would have done with the case now before the court? Is there any reliable information in the legislative hearings or debates on the general type of case before the court? Is there evidence clearly

88. ThAYer, op. cit. supra note $\mathrm{I} 3$, at 429 et seq. See notes $29-32$ supra.

89. ThAYER, Id. at 215; de Sloovère, note 39 supra, at Iog6-Iro3.

90. State v. Kinkead, 57 Conn. I73 (1889) ; Smith v. Lindo, 4 C. B. (N. s.) 395 (I858); cf. Marvel v. Merritt, II6 U. S. II (1885) ; Robertson v. Salomon, I44 U. S. 603 (I892) ; Bogle v. Magone, I52 U. S. 623 (I894).

9r. "No rule of construction, no course of proceeding, is more helpful to a court, in rightfully interpreting a law, than to put itself in the place of the legislative body which passed it, at the time of its enactment, with a complete knowledge of the legislation on its subject at the time, and then to seek, in the light of that legislation, the purpose for which it was passed and the evil it was intended to remedy." (Italics added.) Sanborn, J., in In re Clerkship of Circuit Court, 90 Fed. 248, 25 I (C. C. S. D. Iowa I8g8). 
delineating possible legislative theories, contests of objectives, compromises of purposes, or other persuasive lines of thought relevant to the statutory problem and indicating possible solutions? Finally, will the particular evidence urged for consideration help to resurrect in detail the atmosphere in which the statute was conceived and enacted, as important contextual background for manipulating any interpretative techniques that are legitimate in the process of choosing the best possible meaning the words will fairly bear and in applying that meaning to the case at hand?

Such phases of the textual evolution of a statute as the language of the original bill, ${ }^{92}$ the engrossed bill, ${ }^{93}$ amendments or changes in the bill as proposed in either House in the course of its passage whether enacted or not, ${ }^{94}$ or as adopted and reported by committees of either House, ${ }^{95}$ are generally admissible today. Other bills dealing with the identical subject or problem, though failing of enactment, have also been occasionally admitted; ${ }^{96}$ and these are as legitimate aids as statutes in pari materia which are freely used. In England it has been held that no reference may be made to the original form of the bill. ${ }^{97}$ Indeed, parliamentary history is generally not admissible in England to explain the meaning of a statute. ${ }^{88}$

The next step deals with how far courts use extrinsic aids which go beyond the text from which the bill evolved to discussions of its purposes, its good and bad features, its probable effects and the circumstances which brought about its enactment. Reports of committees

92. Preliminary drafts of the bill. See Blake v. National Banks, 23 Wall. 307 (U. S. I874); Bate Refrigerating Co. v. Sulzberger, I57 U. S. I, 4I (I895); Pennsylvania R. R. v. International Coal Mining Co., 230 U. S. 184, 198-199 (I9I3); United States v. Pfitsch, 256 U. S. 547, 550-5I (I92I). Contra: Parsons v. London, 25 Ont. L. R. I72, aff'd, at 442 (IgII).

93. Field v. Clark, I43 U. S. 649 (I892).

94. Dunlap v. United States, I73 U. S. 65 (I899) ; Carey v. Donohue, 240 U. S. 430 (I9I6); United States v. St. Paul M. \& M. Ry., 247 U. S. 3I0 (IgI7) ; Fox v. Standard Oil Co., 294 U. S. 87 (I935); Travis v. American Cities Co., 192 App. Div. 16, I82 N. Y. Supp. 394 (4th Dep't 1926), aff'd, 233 N. Y. 510, I35 N.' E. 896 (Ig22).

95. Lapina v. Williams, 232 U. S. 78 (1914); Gay v. Ruff, 292 U. S. 25 (I934).

96. See dissenting opinion of Brandeis, J., in Crowell v. Benson, 285 U. S. 22,72 (I932). Successive drafts of the same bill as context: Hood Rubber Co. v. Commissioner of Corporations, 268 Mass. 355, 167 N. E. 670 (1929). Changes made in the light of earlier statutes: Dissenting opinion of Mr. Justice Brandeis in Dahnke-Walker Milling Co. v. Bondurant, 257 U. S. 282, 299 (I92I). Legislative history of another statute on the same subject passed six years later, inadmissible: Pennsylvania Mutual Life Ins. Co. v. Lederer, 252 U. S. 523 (1920).

97. The same rule is occasionally seen here. United States v. Trans-Missouri Freight Ass'n, I66 U. S. 290, 317-18 (I897).

98. See Justices of Lancashire v. Mayor of Rochdale, 8 App. Cas. 494, 50r (I883) per Lord Bramwell, where the value of the history of the act is disapproved in determining its meaning. For other English cases see Gosselin v. King, 33 Can. Sup. Ct. 255 (1903) ; but cf. per Pollock, C. B., in Attorney-General v. Sillem, 2 H. \& C. 43I, at 52r et seq., and per Bramwell, B., 537 (1863) ; River Wear Commissioners v. Adamson, 2 App. Cas. 743,763 (I877); The Queen v. Hertford College, 3 Q. B. D. $693,707(\mathrm{I} 878)$. 
of either House, ${ }^{99}$ special reports for or against the bill by committee members-especially statements of the chairman of the committee ${ }^{100}$ reports of special committees to investigate and report to either House, ${ }^{101}$ and explanatory statements (in supplemental reports) made by a committee member of either House ${ }^{102}$ are generally admitted to aid the court in determining the legislative purposes or objectives. These objectives are of course seen best in the evils existing at the time and discussion of possible means of eliminating them. ${ }^{103} \mathrm{Ex}$ -

99. Reports of committees can be freely used to determine the evils sought to be eliminated and the means of eliminating them as reliable information as to legislative purpose. See Blake v. National Banks, 23 Wall. 307, 319 (U. S. 1874); Bate Refrigerating Co. v. Sulzberger, I57 U. S. I, 42 (I895); Chesapeake \& Potomac Tel. Co. v. Manning, I86 U. S. 238, 245 (I902); Binns v. United States, I94 U. S. 486, 495 (I904); Lapina v. Williams, 232 U. S. 78, 88 (I914); Caminetti v. United States, 242 U. S. 470, 499 (I9I7), dissenting opinion of McKenna, J.; Knickerbocker Ice Co. v. Stewart, 253 U. S. I49, I62 (1920) ; Duplex Printing Press Co. v. Deering, 254 U. S. 443, 474 (I92I) ; United States v. Pfitsch, 256 U. S. 547, 55I (I92I); Ozawa v. United States, 260 U. S. I78, 194 (I922) ; Humphrey's Executor v. United States, 295 U. S. 602, 625 (I935). A committee report may be regarded as a preamble to an ordinance. Second Municipality of New Orleans v. Morgan, I La. Ann. III (I846).

In Church of the Holy Trinity v. United States, I43 U. S. 457 (I892), the Court seriously considered the committee's report in construing the words "labor and service" as meaning "manual labor and service" and found that the committee would have reported the clearer designation of "manual labor and manual service" had they not feared it might delay the bill beyond the session, and had they not felt that the courts would so interpret the words anyhow. Id. at 464 .

English cases, except Regina v. Bishop of Oxford, 4 Q. B. D. 525, 550 (I879) are, however, the other way. See Salkeld v. Johnson, 2 Ex. 256, 273 (I848); Ewart v. Williams, 3 Drew. 2I, 24 (Ch. I854); Attorney-General v. Sillem, 2 H. \& C. 43I, 52I (Ex. I863) ; Regina v. Hertford College, 3 Q. B. D. 693,707 (I878); Rankin v. Lamont, 5 App. Cas. 44, 52 (1880) ; Rex v. West Riding of Yorkshire County Council [I906] 2 K. B. 676, 7I6; Viscountess Rhondda's Claim [I922] 2 A. C. 339, 383; Assam Railways \& Trading Co. v. Commissioners of Inland Revenue [I935] A. C. 445, 457. Some evidence of change from exclusion of Parliamentary record is encouraging. See Rex v. Jeanotte [1932] 2 W. W. R. (Can.) 283, 286; Note (I932) 48 L. Q. REv. I4I, 145 .

Ioo. See Duplex Printing Press Co. v. Deering, 254 U. S. 443, 475 (I92I) ; cf. Bate Refrigerating Co. v. Sulzberger, I57 U. S. I, $4 \mathrm{I}$ (I895). Answers or explanations of members of the committees in charge of the bill, admitted, when making reports to either House as to the legal effect of the bill. See Binns v. United States, 194 U. S. 486,495 (1904); United States v. Wilson, 58 Fed. 768 (N. D. Cal. I893); Wisconsin R. R. Commission v. Chicago, B. \& Q. R. R., 257 U. S. 563, 589 (I922).

IOI. United States v. Pfitsch, 256 U. S. 547, 55I (I92I); United States ex rel. Patton v. Tod, 297 Fed. 385, 393 (C. C. A. 2d, I924); Kneeland v. Emerton, 280 Mass. 37 I, I83 N. E. I55 (I932). In Woodward v. De Graffenried, 238 U. S. 284 (I915), the admission of such a report was limited to inquiries made before the enactment of such legislation. Reports of commissioners appointed to investigate the matter before introducing the bill have been admitted. See Eastman Photographic Materials Co. v. Comptroller-General of Patents [1898] A. C. 57I, 575; cf. Taff Vale Ry. v. Amalgamated Society of Ry. Servants [I90I] A. C. 426,438 . But in State v. Burk, 88 Iowa $66 \mathrm{I}, 56 \mathrm{~N}$. W. I80 (I893) information showing that the commission of pharmacy had consented to the inclusion of a provision in the original act exempting such proprietary medicines as were sold by defendant or the opinion of the legislative committee as to its meaning was held inadmissible.

I02. Binns v. United States, I94 U. S. 486, 495 (I904); United States v. Coca Cola Co., $24 \mathrm{I}$ U. S. 265, 28I (IgI6); United States v. St. Paul M. \& M. R. R., 247 U. S. 30I, 318 (I9I8) ; Duplex Printing Press Co. v. Deering, 254 U. S. 443, 475 (Ig2r); Únited States ex rel. Patton v. Tod, 297 Fed. 385 (C. C. A. 2d, I924); cf. Pennsylvania R. R. v. Int. Coal Mining Co., 230 U. S. I84, I99 (I9I3).

I03. Heydon's Case, 2 Co. (Pt. III) 7, 76 Eng. Rep. R. 637 (I584) and the many cases based on it. 
planatory statements made in debate by the chairman of the committee, however, have not been freely admitted. ${ }^{104}$ If decisions permitting the use of these reports are right, communications or messages concerning the particular legislation from the executive, an executive officer or cabinet member to the legislature or to a commission (though no part of the hearings or report) should also be admissible. ${ }^{105}$ Petitions addressed to committees of Congress showing the need of certain legislation are, on the other hand, only admissible to show the circumstances that existed at the time and as urged upon the legislature by the petitioners. ${ }^{106}$ But such petitions are not admissible, if it is shown that they were not in any way considered by the legislature. ${ }^{107}$

Likewise and for similar purposes, journals of either House, so far as they relate to the bill, ${ }^{108}$ should be sufficiently reliable as aids.

I04. Omaha \& C. B. Street R. R. v. I. C. C., 230 U. S. 324 (I9I3) (inadmissible). Contra: New York \& Cuba Mail S. S. Co. v. United States, 297 Fed. I58 (C. C. A. 2d, I924) (but really explainable as within the rule governing the admissibility of explanatory statements); State ex rel. Corp. Comm. v. Southern Ry., I85 N. C. 435, II7 S. E. 563 (1923).

In United States v. Catz American Co., 53 F. (2d) 425 (C. C. A. 9th, 193I) the court refused to give effect to the meaning of the words "prepared or packed" in the saving clause of the Food and Drugs Act, 34 STAT. 768 (I906), 2I U. S. C. A. \$\$ 2, I4 (I926), as understood by the chairman of the committee that drafted the provision. See (1932) 45 HaRv. L. REv. 1266.

105. See Kepner v. United States, 195 U. S. 100, I22 (1904); Johnson v. Southern Pacific Co., I96 U. S. I, I9-20 (I904). Reports of public officers admissible: Brandeis, J., in Omaechevarria v. Idaho, 246 U. S. 343 (I9r8) (report of Secretary of the Interior; McKenna, J., dissenting in Caminetti v. United States, 242 U. S. 470, 499 (1917). Opinions of the attorney-general: Kirby v. Lewis, 39 Fed. 66 (C. C. Ark. 1889) ; Boston Safe Deposit and Trust Co. v. Commissioner, 273 Mass. 212, I74 N. E. II6 (1930).

I06. See American Net. \& T. Co. v. Worthington, I4I U. S. 468, 473-474 (I89I); Church of the Holy Trinity v. United States, I43 U. S. 457,464 (I892); Ogden v. Strong, 2 Paine 584, rg Fed. Cas. No. 10,460 (no date).

I07. "We did not think the fact that a copy of the report made by the Boston Transit Commission to the City Council of Boston, containing an estimate of $\$ 2,406,000$ as the cost of a tunnel from Maverick Square, East Boston, to a point on Hanover Street along the route marked as Route I on Exhibit 2 was mailed to members of the Legislature soon after their election, can affect the construction to be given to the language under discussion. The report was not made to the Legislature, was doubtless only one of many documents and papers sent to different legislators while in office, and we cannot assume that any member read it, or that if he did he paid any particular attention to Carson's estimate, which was contained in a few lines, or that if he did pay any such attention he was at all influenced by the estimate in voting upon the bill. Nor would the statement of any member that he was so influenced be admissible. Certain general facts of common knowledge, such as some of those agreed upon in this case, may, however, be taken into consideration, under a principle similar to that under which in construing a private contract the circumstances may be shown to enable the court to see the situation of the parties." Hammond, J., in Browne v. Turner, I74 Mass. I50, I59, 54 N. E. 510, 513 (1899). See Thomas v. Vandergrift \& Co., 162 Fed. 645 (C. C. A. 3 d, I908).

ro8. Blake v. National Banks, 23 Wall. 307 (U. S. 1874); United States v. Burr, I59 U. S. 78 (I895); Carey v. Donohue, 240 U. S. 430 (19I6); Penn Mutual Life Ins. Co. v. Lederer, 247 Fed. 559 (E. D. Pa. I9I8); Small v. Small, r29 Pa. 366, I8 Atl. 497 (1889). But see Field v. Clark, I43 U. S. 649, 670 (1892). Earlier, however, journals were not regarded as helpful in finding the meaning of a statute on the ground that "this must be ascertained from the language of the act itself, and the facts connected with the subject on which it is to operate." Southwark Bank v. Commonwealth, $26 \mathrm{~Pa}$. 446, 450 (1856). See also Sedgwick, Construction of Statutory and ConSTITUTIONAL LAW (2d ed. by POMEROY I874) 203. 
Indeed, constitutions sometimes provide for keeping such journals. ${ }^{109}$ Also helpful in this respect are provisions for admission of copies or extracts from the journals of either House if certified by the secretary of the Senate or clerk of the House. ${ }^{110}$ Similarly, the statute record or certificate of the presiding officer should be admissible. ${ }^{111}$ These reports or records are in a sense secondary to the actual textual changes in the evolution of the enacted bill. But they are not secondary as evidence of what objectives and evils to be remedied were in the minds of the legislative bodies at the time, if the mischief to be suppressed and the remedy to be advanced as found in conditions generally surrounding the enactment are at all valuable..$^{112}$

Much misunderstanding is found, however, in the decisions as to how far various elements in debates or discussions on the floor of either House during the enactment are to be considered. For example, it is rather difficult to determine whether courts reject arguments and opinions in debates because they are irrelevant or misleading; or though relevant, entitled to little weight, despite ambiguities in the statute; or because they cannot be brought in for the purpose of raising doubts as to a meaning apparently clear on its face. So far as debates in either House express motives of individual members or personal views as to the meaning or effect of the bill, they are generally inadmissible, ${ }^{113}$ because they are biased and unreliable ${ }^{114}$ as expressive of the ideas of the majority, ${ }^{115}$ and often represent individual political views. ${ }^{116}$ And yet there are some indications today that they should be considered for what they are worth, ${ }^{11 \tau}$ since they do help to indicate statutory ob-

109. See e. g., U. S. Const. Art. I, § 5, cl. 3.

I Io. See e. g., 9 STAT. 80 (I846), 28 U. S. C. A. $\$ 676$ (I928).

II . People v. DeWolf, 62 Ill. 253 (I87I); Duncomb v. Prindle, I2 Iowa I (I86r); Berry v. Baltimore \& D. P. R. R., 4I Md. 446 (I874); Legg v. Mayor, 42 Md. 203 (I874) ; People v. Mahaney, I3 Mich. 481 (1865); Bd. of Supervisors v. Heenan, 2 Minn. 330 (1858); Purdy v. People, 4 Hill 384 (N.' Y. I842).

II2. Heydon's Case, 2 Co. (Pt. III) 7, 76 Eng. Rep. R. 637 (I584) ; United States v. Union Pacific R. R, 9I U. S. 72 (I875); People v. Bd. of Supervisors, 43 N. Y. I30 (I870); Woollcott v. Shubert, 2I7 N. Y. 2I2, III N. E. 829 (I916); Keith v. Quinney, I Ore. 364 (I86I). "Facts which are stated to exist outside the Act of Parliament" are admissible. Green v. Queen, I App. Cas. 513, 531 (1876).

113. Duplex Printing Press Co. v. Deering, 254 U. S. 443, 474 (I92I); Badeau v. United States, 21 Ct. Cl. 48 (1886) ; State v. Lancashire Fire Ins. Co., 66 Ark. 466, 5I S. W. 633,45 L. R. A. 348 (r899). Motives of city ordinance-makers are not to be considered in determining constitutionality. Soon Hing v. Crowley, II3 U. S. 703 (I885). But with ordinances it has been held otherwise as to fraudulent motive. Glascow v. St. Louis, I07 Mo. I98, 17 S. W. 743 (I89r).

I14. See United States v. Trans-Missouri Freight Ass'n, I66 U. S. 290, 316-3I8 (I897); Mutual Benefit Life Ins. Co. v. Duffy, 295 Fed. 88r, 894 (D. N. J. I924), aff'd, 272 U. S. 6r3 (1926).

II 5. See Mitchell v. Great Works Milling \& Mfg. Co., 2 Story 648, I7 Fed. Cas. No. 9,662 , at 498 (C. C. D. Me. I843); Badeau v. United States, 2I Ct. CI. 48,49
(1886).

Ir6. See Downes v. Bidwell, I82 U. S. 244, 254 (I90r).

II7. See Johnson v. Southern Pacific Co., Ig6 U. S. I, 20 (1904) ; Haskell v. Perkins, 28 F. (2d) 222,223 (D. N. J. I928). 
jectives. ${ }^{118}$ They should, of course, be admissible so far as they show facts, conditions, contemporary history ${ }^{118}$ or evils sought to be eliminated or avoided.120 This would seem to follow from the cases upholding the admissibility of individual opinions, as found in debates, which are directed to the question as to what effect would be given by courts to disputed language in the bill. ${ }^{121}$ This attitude seems more justifiable when it is seen that debates are admissible to show probable legislative objectives of ambiguous language. ${ }^{122}$

Upon this entire problem of using the internal history of the bill, the law is uncertain in England where the tendency till recently has been to put rigid restrictions upon using information extrinsic of the statute. Nevertheless, the Lord Chancellor in one case allowed a speech in the House of Lords to be cited as an authority in the construction of a statute. ${ }^{123}$ In the United States, briefs of counsel for groups variously interested in proposed legislation have also been considered. ${ }^{124}$ Naturally, memoranda of legislative counsel of either House, who are impartially concerned with the reasons for and against such legislation and can presumably deal impartially with evils, remedies and objectives, should be given considerable weight. ${ }^{125}$ A speech of the proponent of the statute has even been resorted to in order to determine the scope of the statute. ${ }^{126}$

All of these materials, so far discussed, constitute the legislative or internal history of the legislation. ${ }^{127}$ Present language techniques

II8. See Roberts v. Southern Pacific Co., 186 Fed. 934, 938 (C. C. S. D. Cal. I911), aff'd, 219 Fed. ro22 (C. C. A. 9th, I9I5). But see People v. Chicago Rys., 270 Iil. 87,105 , IIO N. E. 386,393 (1915).

II9. See Jennison v. Kirk, 98 U. S. 453,459 (1878) ; Binns v. United States, I94 U. S. 486, 495 (1904); Standard Oil Co. v. United States, 221 U. S. I, 50 (I9II), per White, C. J.; United States v. St. Paul M. \& M. R. R.,' 247 U. S. 3I0, 318 (I918).

I20. See American Net. \& T. Co. v. Worthington, I4I U. S. 468, 473 (I89I) ; Standard Oil Co. v. United States, 22 I U. S. I, 50 (19II); Woollcott v. Shubert, 217 N. Y. 2I2, 22I, III N. E. 829, 833 (I9r6). Debates "may be resorted to for the purpose of ascertaining the situation which prompted this legislation". Day, J., in Tap Line Cases, 234 U. S. I, 27 (1914).

I2r. See Ackiin v. People's Saving Ass'n, 293 Fed. 392, 397 (N. D. Ohio 1923). Why debates cannot be used to show the meanings of words is difficult to see. But see McCaughn v. Hershey Chocolate Co., 283 U. S. 488, 493 (I93I) ; Rathburn v. United States, 295 U. S. 602, 625 (1935).

122. Federal Trade Commission v. Radladam Co., 283 U. S. 643 (I93I); Work v. United States ex rel. Rives, 295 Fed. 225 (App. D. C. Ig24).

123. Bramwell and Baggallay, L. JJ., in Queen v. Bishop of Oxford, 4 Q. B. D.

525 (I879). See South Eastern Ry. v. Commissioners, 5 Q. B. D. 217, 236 (I880), where Cockburn, C. J, referred to a speech by a person who was then introducing the bill into Parliament. For other English cases see note 99 supra.

I24. See Penn. Mutual Life Ins. Co. v. Lederer, 252 U. S. 523, 534 (I920). But see Mutual Benefit Life Ins. Co. v. Duffy, 295 Fed. 88I, 894 (1924).

125. Policies of the government, however, have been regarded as too uncertain for determining statutory meaning. Hadden v. Collector, 5 Wall. I07 (U. S. r866). But cf. cases on legislative policy: Commonwealth v. Barney, rr5 Ky. $475,74 \mathrm{~S}$. W. r8r (Ig03); Jewell v. City of Ithaca, 36 Misc. 498 , 73 N. Y. Supp. 953 (rgor).

126. Ex parte Peede, 75 Tex. Crim. Rep. 247, 258, i70 S. W. 749, 753 (1914).

I27. Legislative history of the statute is generally admissible. Chesapeake \& Potomac Tel. Co. v. Manning, I86 U. S. 238, 242-244 (1902); United States v. Pfitsch, 256 U. S. 547, 550-55I (I92I) (as found in the Congressional Record); Wright v. 
could be made more effective if courts would be more flexible in resorting to these materials and more discriminatory in evaluating them with respect to the particular issue involved. ${ }^{128}$ This approach could be facilitated by extending the doctrine of judicial notice to these matters generally. As courts take judicial notice of the meaning of words in a statute, logically they are, and should be, permitted, as a legal matter collateral to determining such meaning, to refresh their recollection of the entire background of the legislation. ${ }^{129}$

On the other hand, opinions of legislators either at the time of enactment or later, as to what the legislature had in mind in enacting a particular statute are probably so unreliable that they ought to be excluded entirely. Their admission really presumes the existence of a discoverable legisiative intention with respect to the application of the statute in the case at hand, and likewise assumes a similarity of the individual opinion with that of the majority. The former is seldom more than a fiction, and the latter is clearly incapable of proof. Such opinions as to specific applications of a statute, whether found in debates ${ }^{130}$ or as testimony in court or at committee hearings, ${ }^{131}$ should

Vinton Branch, 300 U. S. 440 (1937) ; Supervisors of Niagara v. People, 7 Hill 504, 5 II (N. Y. 1844); Wiley v. Solvay Process Co., 2I5 N. Y. 584, 109 N. E. 606 (Igr5); Woollcott v. Shubert, 217 N. Y. 212, III N. E. 829 (I916) ; Scounten v. Whatcom, 33 Wash. 273, 74 Pac. 389 (1903); Attorney General v. Brown, [1920] I K. B. 773 . Cf. Legislative history of the term "Indian country" regarded as important. United States v. McGowan, 302 U. S. 535 (1938). See also Crares, Statute Law (Ig23) I22.

128. Gutteridge, note 48 sippra, at 7.

129. State Board of Pharmacy v. Matthews, I97 N. Y. 353, 90 N. E. 966 (I910), Judicial notice, which functions as a substitute for proof, is clearly of value at this point; but its treatment is not within the province of this paper. Courts do generally, however, judicially notice circumstances concerning the enactment of a statute: Preston v. Browder, I Wheat. II5 (U. S. I8I6) ; United States v. Union Pacific R. R., 9I U. S. 72 (1875) ; Dunlap v. United States, 173 U. S. 65 (1899) ; McLelland v. Shaw, I5 Tex. 319 (I855). As to judicial notice of historical and other facts relative to legislation, see Delaplane v. Crenshaw \& Fisher, I5 Gratt. 457, 459 (Va. I860) and generally, SUTHERLAND, note I8 supra, $\$ \$ 463-47 \mathrm{I}$.

How far, in questions of constitutionality of statutes, extrinsic evidence should be admitted beyond facts of which courts take judicial notice is not dealt with in this paper. See Barnett, External Evidence of the Constitutionality of Statutes (1924) 58 AM. L. REV. 88, 95-96. The present rule restricting the use of extrinsic facts to what may be judicially noticed is also due, perhaps, to fear of uncertainty in constitutional law. "Courts cannot make an issue of fact, or review the facts as such, upon which the legislature must be presumed to have passed, in order to determine the validity of an act of the legislature." Hovey y. Foster, II 8 Ind. 502, 508, 2I N. E. 39, 4I (I889).

Unquestionably, the problem involves some delicate questions of policy and the delicate balancing of interests. "But there is a manifest absurdity in allowing any tribunal, either court or jury, to determine from testimony in the case the question of the constitutionality of the law. . . . The first case presented might show by the opinions of many witnesses that the use of the dry emery wheel is almost necessarily fatal to the operator, while the next might show exactly the opposite state of facts. Manifestly, then, the decision could not settle the question for other parties, or the fate of the law would depend upon the character of the case first presented to the court of last resort, which would have no means of ascertaining whether it was a collusive case or not, or whether the weight of evidence was in accord with the truth." People v. Smith, 108 Mich. 527, 533, 66 N. W. 382, 383 (1896). See also ten Broek, note I supra.

There are tendencies, at any rate, toward a wider view regarding the use of external evidence in this important phase of interpretation. See Barnett, supra at 98.

I30. Gray, The Nature aNd Sources of THE LAW (2d ed. I92I) I72, I73.

I3I. Delaplane v. Crenshaw \& Fisher, I5 Gratt. 457, 479 (Va. I860). 
perhaps be excluded as irrelevant. But when in any of these situations a legislator's views as to evils, remedies, or objectives of the bill are sought, technically they should be admissible ${ }^{132}$ as part of the composite, contextual background, since they aid somewhat in completing the picture of what the legislature as a whole was trying to do. In accordance with this distinction, a judge, who was either a member of the legislature when the statute was enacted or drew the bill and who thus has special knowledge of its history, ${ }^{133}$ should not refrain from applying that knowledge so far as it relates to evils, conditions of the time, legislative objectives, and the history of the legislation as he recalls them, but should refrain, if possible, from applying his individual opinion as so crystallized to the case at hand.

If courts find it necessary to place themselves as completely as possible in the position of the legislative body, in order to glean such knowledge of the difficulties and the evils as they can from the history of the bill at the time of its enactment, ${ }^{134}$ the public or external history of the times ${ }^{135}$ then becomes very important in determining the meaning of the legislation. This relates to social, ${ }^{136}$ economic, ${ }^{137}$ or political evils or conditions of the time and place, which are relevant to the enactment of such legislation as well as to defects in existing law, ${ }^{138}$ which are in

132. See Stafford v. Wallace, 258 U. S. 495, 513 (1922).

133. The cases do not distinguish the two types of knowledge and perhaps they are actually inseparable. For example, in Ash v. Abdy, 3 Swans. 663, 36 Eng. Rep. R. Ior4 (I678), Lord Nottingham said that he "had some reason to know the meaning of this law; for it had its first rise from me, who brought in the bill into the Lords' House". Ibid. See Leahy v. Timon, IIo Tex. 73, 215 S. W. 95I (I919), in which reference is made to a case in which the judge applying the code was a member of the Code Commission. Id. at 78, $215 \mathrm{~S}$. W. at 953 . Ability of draftsman to write succinctly is considered by Lord Kenyon in Rex v. Wallis, $5 \mathrm{~T}$. R. 375, 379, Ior Eng. Rep. R. 210, 212 (1793). But see Hilder v. Dexter [1902] A. C. 474, 477, where according to Lord Halsbury the worst person to construe a statute is the one who drafted it, as he is likely to confuse what it says with what he himself intended. See also Smith, note 21 supra, at 155 .

I34. Stafford v. Wallace, 258 U. S. 495, $5 \mathrm{I3}$ (I922) ; In re Clerkship of the Circuit Court, 90 Fed. 248, 251 (C. C. S. D. Iowa I 898 ).

I35. In case of ambiguity, public history of the times is admissible. Aldridge v. Williams, 3 How. 9,24 (U. S. I845); United States v. Pacific R. R., 9I U. S. 72, 79 (1875); United States v. Trans-Missouri Freight Ass'n, I66 U. S. 290, 318-319 (I897). A notorious fact as to where the crime was usually committed is regarded. Regina v. Zulueta, I Car. \& K. 215, I74 Eng. Rep. R. 78 (I843). Geographical relation of Hong-Kong to China and other circumstances are considered. Attorney-General v. Kwok-a-Sing, L. R. 5 P. C. I79, I97 (I873). Are relevant circumstances limited to those which are contemporary and within the knowledge of the legislature at the time of enactment? See State v. Harden, 62 W. Va. 313, 60 S. E. 394 (Ig07).

I36. Relevant social conditions and customs at the time of enactment are admissible. Hockett v. State, I05 Ind. 250, 5 N. E. I78 (I886).

I37. American Net \& T. Co. v. Worthington, I4I U. S. 468 (I8gr) ; Church of the Holy Trinity v. United States, I 43 U. S. 457,463 (I892); The Tap Line Cases, 234 U. S. I, 27 (IgI4), per Mr. Justice Day.

I38. Evil or mischief to be remedied as determining purpose of legislation: Keith v. Quinney, I Ore. 364 (I86I) ; Big Black Creek Improvement Co. v. Commonwealth, 94 Pa. 450 (I880); Clark v. Janesville, Io Wis. 136 , I65 (1859); Heydon's Case, 3 Co. (pt. III) 7a, 76 Eng. Rep. R. 637 (K. B. 1584); Hawkins v. Gathercole, 6 DeG. M. \& G. I, 43 Eng. Rep. R. II29 (Ch. I855) ; BLACKstone, Commentaries (Chase I896) 52. Cf. Dodge v. Gardiner, 3I N. Y. 239 (I864). 
turn exemplified by public opinion and popular ideas of justice as found in sources other than those dealing directly with the enactment. ${ }^{139}$ Little conflict of opinion seems to exist with respect to the full use of these aids. Similarly, no conflict seems to have grown up with respect to the free use of ancient and classic treatises of the common law. ${ }^{140}$ Likewise, text books and dictionaries are freely consulted to determine the meaning of statutory words or phrases. ${ }^{141}$ And of course, any fact of which a court may take judicial notice may also be used in any problem of statutory construction.

\section{Some Conclusions Concerning the Effective Use of EXTRINSIC AIDS}

I. As interpreting a statute is a question of law and as all extrinsic aids (such as the internal history of its enactment and contemporaneous facts and conditions) ought to be judicially noticed, courts should be permitted to consult and evaluate any such aids in determining the statutory meaning in any case.

2. No rules defining what may be consulted in reaching the meaning of a written instrument-whether the parol evidence rule, ordinary rules of evidence or special rules relating to interpretation of deeds and wills or other writings-should be considered even by the closest apparent analogies to be binding precedents in construing a statute. Although the interpretation of statutes and other writings have certain similarities, essentially they are different problems.

3. Materials extrinsic to a statute should be consulted not only when making a choice between two or more possible meanings of the text itself, but in checking up an apparently plain and explicit meaning, in finding other possible meanings not apparent in the text, and in applying the chosen meaning to the case at hand.

4. No exclusionary rules differentiating types of extrinsic aids should deter courts from considering and evaluating such aids in relation to the particular problem. Of course, opinions of legislators are of little weight; but statements of fact concerning evils to be remedied, contemporary conditions, and the objectives of the legislation, as found in debates or in reports of committees or the journals of either House,

I39. Keyport Co. v. Farmers' Transportation Co., 3 Green I3 (N. J. Eq. I866); Delaplane v. Crenshaw \& Fisher, I5 Gratt. 457 (Va. I860).

I40. Rex v. Casement [I9I7] I K. B. 98 .

I4I. In re Warner's Estates, I7 Ch. Div. 7II, 7r3 (I88I). Also meanings of technical terms whether of law or some other science may be determined by reference to standard dictionaries of the particular science. Queen v. Peters, L. R. I6 Q. B. D. 636, 64I (I886); Bank of Toronto v. Lambe, I2 App. Cas. 575, 581 (I887) ; In re Castioni [I89I] I Q. B. I49, I53; Brewers, etc., Ass'n of Ontario v. Attorney-General for Ontario [I897] A. C. 23I, 236 . For an interesting example of the use of dictionaries and encyclopedias, see United States v. Thind, $26 \mathrm{I}$ U. S. 204 (1923). 
though always admissible, are significant only insofar as they shed light upon the particular problem of statutory interpretation.

5. Whenever the court is to leave to the jury not the interpretation of a statute (i. e., choosing from possible meanings thereof), but rather the application of the meaning of ordinary words or phrases in a statute to the particular facts of the case, every reason for following rules of evidence in determining what extrinsic aids should go to the jury is again cogent, since a jury may be misled as much by this kind of evidence as any other. Although it is seldom that this question of the use of extrinsic aids by a jury arises, the problem does present itself whenever a judge believes that the jury can satisfactorily determine the meaning of popular terms.

6. That a plain and explicit statute needs no construction and that extrinsic aids cannot be admitted for the purpose of contradicting a plain meaning are rules that ignore obvious difficulties in distinguishing "contradicting" from "explaining". Finding from extrinsic facts a contextual meaning which the words will fairly bear, and which better accords with the statutory purpose, brings to light an ambiguity in language which was assumed to be clear and explicit. In such a case extrinsic aids do not contradict the plain meaning but show that the meaning was never plain. If, as is often said, the phrase "plain and explicit meaning" indicates that it is the only meaning the words will bear, then the rules suggested beg the question, because they shut out the use of the broadest contextual background as determined by extrinsic aids. All possibilities of the existence of other reasonable meanings are therefore cut off. This becomes even more distressing, since by such reasoning neither meaning nor purpose can be checked whenever there is an apparently plain meaning. Indeed, one of the simplest forms of ambiguity is inconsistency between meaning and purpose. Thus the theory of all satisfactory construction-that all interpretation must further so far as possible the objectives of the legislation-is curtailed, if a thoroughigoing, factual search for objectives in extrinsic aids is prevented. A check-up, on the basis of extrinsic aids, may well show the purpose of the legislature to be somewhat different from what the text indicates; and when this occurs, the obvious meaning is no longer plain, as it is now inconsistent with actual legislative objectives. In short, extrinsic aids may not only show that what appears to be plain is really ambiguous, but that another meaning more consonant with the immediate ends of the legislation is more sound and satisfactory. It follows that the current belief-giving an obvious meaning such superiority over a sensible, contextual meaning as to preclude consid- 
eration of the statutory purpose as gleaned from extrinsic aids-is erroneous.

7. An obvious meaning should naturally be regarded as superior to all others, if after a survey of all extrinsic materials, it is more consistent with all other parts of the statute and with the legislative objectives than any other. Only then should it be said that a plain and explicit meaning can neither be contradicted nor explained away.

8. If the literal or grammatical meaning of the language is consistent with both the plain purpose of the statute and all other parts thereof, common sense suggests that no extrinsic evidence could possibly be of such weight as to render ambiguous a meaning apparently so plain. But at this point courts must deal with the problem of the weight of the evidence rather than with any attempt at excluding it from consideration. In each case, therefore, the persuasiveness of an apparently plain meaning, as compared with that of other probable meanings, does not involve a question of exclusion or non-exclusion of extrinsic aids, but rather one of evaluation of such aids in relation to all aspects of the specific problems of interpretation in the case at hand.

9. Within these limitations and subject to the qualification that the meaning finally chosen must be one that the statutory language will honestly bear, courts on choosing the most desirable construction, should exercise the widest possible freedom with regard to the use of extrinsic aids in $\operatorname{order}(\mathrm{I})$ to determine the precise subject-matter of the legislation; (2) to penetrate as deeply as possible into the contextual implications of the language; (3) to obtain the clearest possible picture of legislative objectives; and (4) to facilitate applying such meaning more intelligently and with greater exactitude to the case at hand.

Io. To set down rules of exclusion (even with respect to personal opinions of legislators in debates on the floor of either House) or to evaluate particular types of extrinsic aids, in and of themselves, is misleading, even if it could be done. It is also submitted that courts should base the use of exclusion of particular types of extrinsic materials rather more on their immediate cogency to close issues of meaning in each case than on the intrinsic value of the particular type of material.

II. Finally, it would seem that if the techniques suggested herein be followed in the use of materials extrinsic to a statute in the attempt to find and apply its meaning, statutory interpretation will become less a matter of applying general canons of construction and more a matter of following definite indications of meaning extant in the history of the 
legislation. Speculating as to statutory meanings and objectives will be replaced by a more exact and effective carrying out of legislative will. Mr. Justice Holmes tells us, however, that basing "speculations about the purposes or construction of a statute upon the vicissitudes of its passage" is a delicate business. ${ }^{142}$ But it is an equally delicate business to base statutory meanings on general canons of construction and present exclusionary rules governing the use of extrinsic aids. At all events the attempt must be made; and it can be successful, without sacrificing any of the safeguards that rules of exclusion now attempt to secure, if it is remembered that no meaning is proper if it is one the words will not bear by fair use of language.

That contextual techniques for interpreting legislation are in the nature of things finely spun processes is no reason for disregarding them in construing complicated legislation. Techniques for the use of extrinsic aids or evidence should therefore aim to encourage courts to widen the contextual background of legislation and to bring to light situations where such evidence is likely to aid in statutory interpretation.

142. Pine Hill Coal Co., Inc. v. United States, 259 U. S. I9I, I96 (I922). 